\title{
Development of Education and Training Models in Improving the Professionalism of Economic Teachers
}

\author{
Neti Budiwati ${ }^{\mathbf{1}}$, Ani Pinayani ${ }^{\mathbf{2}}$, Yana Rohmana ${ }^{3}$ \\ 1,2,3Faculty of Economic and Business Education, Universitas Pendidikan Indonesia, \\ Bandung, Indonesia
}

\begin{abstract}
The aim to develop models of education and training that are effective in improving teacher competencies. The research method uses non-experimental explanatory and R \& D method. The research sample is a high school economic teacher in the Greater Bandung area. Data collection using a questionnaire. Based on the education and training model that was once followed by economic teachers, the results of the research showed that teachers of professional education and training are very helpful in improving teacher professionalism, the form of online learning is very difficult for teachers, especially those in remote areas. Therefore teachers strongly agree to use faceto-face patterns and material support in improving teacher professionalism. Besides that the teacher strongly agrees that the Teacher Professional Education and Training and the teacher learning program with online mentoring can improve literacy and teachers who support professionalism. Teachers state patterns of teacher certification through Professional Education and Training Teachers should focus on professional competence. This study can determine the alternative development of the Teacher's Professional Education and Training model in positions and models, namely Teacher Professional Education and Training using blended learning and Teacher Education and Training Model Based on needs.
\end{abstract}

Keywords: Education and Training, Teacher Professionalism.

Correspondence.netibudiwati@upi.edu

Article History. Received January 2019, Received in revised March 2019, Accepted June 2019

O2019. International Journal Pedagogy of Social Studies. Department of Social Studies Education

\section{A. INTRODUCTION}

Increased competence and performance of teachers can be done through education and training (in service training), and of course for teachers who have worked through the on the job method (Busono, G. A., 2016). Even Noe, et.al. (2003) argues, "training is a planned effort to facilitate learning of job-related knowledge, skills, and behavior by employee". This means that education and training must be planned so that its effectiveness is achieved, because effectiveness is the utilization of facilities and infrastructure resources in a certain amount that is consciously set beforehand to produce a number of goods for the services carried out.
Therefore, in the framework of implementing the 2013 curriculum, a continuous effort is needed to improve the competence of the teacher. So the government through the Ministry of Education and Culture has perfected the education system namely the guidance and improvement of teacher competency through the Sustainable Professional Development program. Continuous professional development this is the key for teachers to optimize their career development opportunities both now and in the future as sustainable self-development. In addition to Sustainable Professional Development, there are several teacher professional development programs developed by the government and 
independently by schools or training institutions. The program included the Teacher Training and Education Program which was originally in the form of face-to-face and then combined with online training, as well as Teacher Professional Education in the form of workshops and for Professional Education Teachers in positions in the form of hybrid learning, Technical Guidance (Bimtek), In house training and others. Not all of these education and training programs are effective in enhancing teacher professionalism, including the program of Continuous Professional Development activities (continuity professional development) also seen as not yet effective in improving teacher professionalism.

Vyas (2004) states that evaluation is the most important way to determine the effectiveness of training. Other factors also have an influence on the effectiveness of training, such as learning transfer, the ability of the trainer to convey material, the ability of participants to absorb material and the ability of institutions and trainers to recognize the needs of participants, and the suitability of training packages to the needs of participants. Professional teachers should be carried out continuously (Continuing Professional Development for Teachers), for example by forming Professionalism Learning Community (PLC).

The ineffectiveness of the various teacher training programs is caused by (i) the implementation of the program is not based on the real needs of the teacher, so that the teacher in following is of the origin and attendance (Darwangsa, 2013), (ii) not paying attention to the shortcomings of the individual teacher ( Ministry of National Education, 2008), (iii) organizing programs that are still projectoriented, budget-based, mass-based (Jalmo and Rustaman, 2010), and establishing programs that are not based on assessing teacher needs about what forms and activities of training are actually needed by teachers in developing his professionalism (Nugraha, 2012). Thus, training programs that are not based on the real needs of teachers will not have an impact on improving teacher competency and can even reduce teacher motivation, waste of time, effort, and budget (Darling-Hammond, 2006).

Teacher professional development must be considered a long-term process (VillegasReimers, 2003) which begins with initial preparation and only ends when the teacher retires from his profession. New approaches to education and teacher development require the transformation of processes and policies that support their work and growth in the profession. Professional development of teachers in addition to being systematically planned, must also be supported and funded and researched to ensure the effectiveness of the process.

Specifically, the research aims to find out: 1) whether teacher education and training in order to improve existing and current competencies has been viewed has been effective; and 2) can find education and training models that are considered to improve teacher competency and professionalism.

\section{B. METHOD}

This research is a development research (Research and Development) adopting Four-D Models developed by Thiagarajan, et al (Piter Joko Nugroho, 2017) consisting of 4 (four) stages, namely: define phase, design phase, development stage, and disseminate stage. The first phase of research from this multi-year study aims to carry out a define phase that is carried out through training needs analysis. The results of this training needs analysis will then be used as a reference in carrying out the stages of subsequent development research.

Characteristics of development, namely: 1) products based on problems encountered in learning; 2 ) developed through design and trial; 3) the trial was carried out in three stages, namely expert test, empirical test, and field 
test; and 4) products produced in the form of training models.

The subject of this study was the high school economics teacher throughout Bandung Raya. Data collection techniques used in this study are: interviews, questionnaires, and documentation. The research approach used in this study is a qualitative and quantitative approach. The qualitative approach is used to describe the data obtained during preliminary research. Quantitative approaches are used in the implementation of model design, and to test the effective

\section{RESULTS AND DISCUSSION}

Based on research on high school economics teachers about the implementation of education and training that had been followed showed the results of the study as follows:

From the aspect of education and training material, most teachers $51.18 \%$ stated that educational materials and training should focus more on topics related to the mastery of teaching materials. Furthermore, the themes / topics discussed at the Subject Teachers' Meeting or the Association of Subject Teachers, $69.29 \%$ of teachers suggested that the topic / theme should be related to the teacher's needs in improving the quality of learning. $36.22 \%$ of teachers think that pedagogic material is very important to be appointed in education and training activities.

From the aspect of the educational and training material resource persons, $22.83 \%$ of teachers stated that instructors or educational and training resource persons were better from the official structural circles (Education Agency and related institutions).

Most teachers $40.9 \%$ stated that education and training (In House Technical / Educational Training / Guidance and other training) held by schools or related offices \& nbsp; are not only a formality. $33.07 \%$ of teachers stated that education and training held by academics / universities were better (effective) than those held by the school / official. Only $29.92 \%$ of teachers agreed that participating in education and training had not only been required by the school. $25.20 \%$ the teacher strongly agrees that the period or duration of education and training (outside of the Teacher Professional Education and Training) should not exceed 3 days.
As many as $39.37 \%$ of teachers strongly agree that the effective Model / Method used in education and training is in the form of workshops that produce specific products or targets. For example, the development workshop for teaching materials will produce a set of teaching materials.

The training pattern of training for teachers both in the In House Training \& Technical Guidance and Technical Guidance and other forms of education / training held by schools and related agencies, most of the teachers $62.99 \%$ teachers stated that they provided many benefits for teacher professional improvement. $40.94 \%$ teachers strongly agree that teacher professionalism development is more appropriate through the subject of the Subject Teachers' Meeting or the Association of Subject Teachers.

The results of the research on the high school economic teachers about the implementation of the teaching profession education and training that he had followed showed the results of the study that most of the $40.94 \%$ teachers stated that the Teacher Professional Education and Training the teacher had been very effective in improving teacher professionalism. $34.65 \%$ teachers state that online learning / mentoring (teacher learning) is very difficult for teachers, especially those in remote areas. $40.16 \%$ of teachers strongly agree that the pattern and material of the Teacher Professional Education and Training face to face is very supportive in improving teacher professionalism. $31.50 \%$ of teachers strongly agree that the teacher professional education and training as well as the learner teacher program with online learning / mentoring can improve teacher literacy and competence that support professionalism. The pattern of teacher certification through teacher professional education and training, $37.80 \%$ of teachers stated that they should focus on professional competence (strengthening mastery of teaching material).

Two education and training models are tried to be offered as an alternative model of teacher education and training which is expected to increase the professionalism of economic teachers. Which model will be chosen is determined by the results of the trials of the two models in the field. 


\begin{tabular}{|c|c|c|c|c|}
\hline \multicolumn{5}{|c|}{$\begin{array}{l}\text { Teacher's Professional Education and Training Model } \\
\text { which has been and is being carried out }\end{array}$} \\
\hline \multicolumn{5}{|c|}{$\mathrm{F}$} \\
\hline \multirow[t]{2}{*}{$\begin{array}{l}\text { Education } \\
\text { and Training } \\
\text { Models }\end{array}$} & \multirow{2}{*}{$\begin{array}{c}\text { Teacher's } \\
\text { Professional } \\
\text { Education and } \\
\text { Training }\end{array}$} & \multirow[t]{2}{*}{$\begin{array}{c}\text { Teacher's Professional } \\
\text { Education and Training } \\
+ \text { online }\end{array}$} & \multicolumn{2}{|c|}{$\begin{array}{c}\text { Teacher's Professional Education and } \\
\text { Training Models Blended learning/ } \\
\text { Hybrid learning }\end{array}$} \\
\hline & & & online & Non line \\
\hline Time & 9 days & 9 days + online & 6 months & 6 months \\
\hline $\begin{array}{l}\text { Teaching } \\
\text { Material }\end{array}$ & $\begin{array}{l}\text { Teacher } \\
\text { Profession } \\
\text { Paedagogical } \\
\text { Content } \\
\text { Lesson } \\
\text { PlanWorkshop } \\
\text { Action Research } \\
\text { Peer teaching } \\
\text { Local written } \\
\text { Exam } \\
\text { National written } \\
\text { Exam }\end{array}$ & $\begin{array}{l}\text { Teacher Profession } \\
\text { Paedagogical } \\
\text { Content } \\
\text { Lesson PlanWorkshop } \\
\text { Action Research } \\
\text { Peer teaching } \\
\text { Local written Exam } \\
\text { National written Exam }\end{array}$ & $\begin{array}{l}\text { Online } 3 \text { days } \\
\text { Paedagogical } \\
\text { Profesionalisme } \\
\text { Workshop } 5 \\
\text { weeks } \\
\text { Review } \\
\text { Action Research } \\
\text { Teaching Practice } \\
3 \text { weeks } \\
\text { Performance Test }\end{array}$ & $\begin{array}{l}\text { Modul } 3 \text { months } \\
\text { Paedagogical } \\
\text { Profesionalisme } \\
\text { Workshop } 5 \text { weeks } \\
\text { Review } \\
\text { Action Research } \\
\text { Teaching Practice } 3 \\
\text { weeks } \\
\text { Performance Test }\end{array}$ \\
\hline $\begin{array}{l}\text { Speaker/ } \\
\text { Instructur }\end{array}$ & Lecturer & Lecturer & Lecturer & $\begin{array}{l}\text { Lecturer } \\
\text { Trainers } \\
\text { Quality Assurance } \\
\text { Agency }\end{array}$ \\
\hline Place & Hotel/Homestead & Hotel/Homestead & $\begin{array}{l}\text { Home } \\
\text { Hostel } \\
\text { Rented room } \\
\text { Partner School }\end{array}$ & $\begin{array}{l}\text { Home } \\
\text { Hostel } \\
\text { Rented room } \\
\text { Partner School }\end{array}$ \\
\hline Organizer & University & University & University & University \\
\hline & Modification & $\begin{array}{l}\text { ALTERNATIVE } \\
\text { ducation and Training } \\
\text { f Blended learning/ Hy }\end{array}$ & $\begin{array}{l}\text { Models } \\
\text { rid learning Mode }\end{array}$ & \\
\hline Time & & 6 bulan ( 24 minggu & & \\
\hline Teaching Mate & & $\begin{array}{l}\text { Online } 7 \text { weeks : Pe } \\
\text { Lesson PlanWorksh } \\
\text { Review } \\
\text { Lesson Study } \\
\text { Action Research } \\
\text { Performance Test }\end{array}$ & $\begin{array}{l}\text { agogical and Prof } \\
\text { p- } 6 \text { weeks }\end{array}$ & ssionalism \\
\hline Speaker/Instru & & Lecturer & & \\
\hline Place & & $\begin{array}{l}\text { Home } \\
\text { Hostel } \\
\text { Rented room } \\
\text { Partner School } \\
\end{array}$ & & \\
\hline Organizer & & University & & \\
\hline
\end{tabular}




\begin{tabular}{|l|l|}
\hline \multicolumn{2}{|c|}{ Teacher Education and Training Model Based on needs } \\
\hline Time & 6 bulan \\
\hline Teaching Material & online : Paedagogical and Profesionalisme \\
& $\begin{array}{l}\text { Once a month FGD Pedagogic and Professional Material as } \\
\text { Needed (field needs) }\end{array}$ \\
\hline Speaker/Instructur & $\begin{array}{l}\text { Lecturer } \\
\text { Tecaher /National IInstructur }\end{array}$ \\
\hline Place & $\begin{array}{l}\text { Partner School } \\
\text { Campus of University }\end{array}$ \\
\hline Organizer & University \\
\hline
\end{tabular}

\section{CONCLUSION}

Professional teachers are a particular necessity in meeting 21 st century learning. The success of learning and education in general is largely determined by the presence of professional teachers, as well as in economic learning in secondary schools. Therefore efforts to increase teacher professionalism continue to be carried out through evaluations of teacher education and training models that have been running. The effectiveness of education and training is determined by several factors, including material, resource persons, and implementation time.

This research offers two alternative models of teacher Education and training, are Education and Training Models Modification of Blended learning/ Hybrid learning Models, and Teacher Education and Training Model Based on needs. Both alternative models are seen as more effective than previous teacher education and training models, because they integrate various models that have ever existed, as well as the flexibility of the implementation time.

\section{REFERENCES}

Busono, G. A. (2016). Pengaruh Sistem Pelatihan Dan Pengembangan Karyawan Terhadap Kinerja Karyawan Pt. Persada Sawit Mas (PSM) Kecamatan Pampangan Kabupaten Ogan Komering Ilir.

Darling-Hammond, L. (2006). Powerful Teacher Education: Lesson from Exemplary Program. US: Jossey-Bass.

Darwangsa. (2013). Pengembangan Model Diklat Partisipatif - Kolaboratif (Parkol) untuk Meningkatkan Kompetensi Guru Biologi SMA.
Disertasi tidak diterbitkan. Bandung: Universitas Pendidikan Indonesia.

Depdiknas. (2008). Laporan Monitoring dan Evaluasi (Monev) Sertifikasi Guru dalam Jabatan Melalui Portofolio Tahun 20062007. Jakarta: Konsorsium Sertifikasi Guru.

Noe, Hollenbeck, Gerhart, Wright. (2003). Human Resource Management, International Edition. New York: The McGraw-hill Companies, Inc.

Nugroho, P. J. (2012). Pengembangan Profesionalisme Guru Sekolah Dasar pada Daerah terpencil Kabupaten Gunung Mas. Jurnal Manajemen Pendidikan. 23 (6): 513-531. ISSN: 0852-1921.

Nugroho, P. J. (2017). Pengembangan Model Pelatihan Inovatif Untuk Meningkatkan Kompetensi Guru Sekolah Dasar Daerah Terpencil. Sekolah Dasar, Tahun 26 Nomor 2, November 2017, hlm 101-115

Jalmo, T., dan Rustaman, N. Y. (2010). Pengembangan Program Pelatihan Peningkatan Kompetensi Guru IPA SMP. Forum Pendidikan. 30 (1): 79-89.

Villegas-Reimers, E. (2003). Teacher Proffesional Development: an International Review of the Literature. Paris: UNESCO. International Institute for Educational Planning.

Vyas, L. (2004). "Delivering Better Government: Assessing the Effectiveness of Public Service Training in India". Public Personnel Management. 33, (3), 291-306. 